\title{
Exogenous cannabinoids as substrates, inhibitors, and inducers of human drug metabolizing enzymes: A systematic review.
}

Stephen M. Stout, PharmD, MS, BCPS, Nina M. Cimino, PharmD

From: Metabolism, Interactions, \& Genomics Group, Wolters Kluwer Health | Clinical Solutions, Hudson, $\mathrm{OH}$ (SMS); and University of Maryland School of Pharmacy, Baltimore, MD (NMC)

Correspondence:

Stephen M. Stout, Pharm.D., M.S., BCPS

Pharmacotherapy Specialist

Metabolism, Interactions, \& Genomics Group

Wolters Kluwer Health | Clinical Solutions

1100 Terex Rd

Hudson, OH 44236

(1) 517.449 .9286 mobile

(1) 330.656 .4307 fax

smstout@umich.edu

Nina M. Cimino, Pharm.D.

PGY-2 Pain Management and Palliative Care ResidentUniversity of Maryland School of Pharmacy20 North Pine Street, Room S436Baltimore, MD 21201 (1) 734.306 .1168 mobile ninamcimino@gmail.com

Key words: enzymes and coenzymes, drug interactions, tetrahydrocannabinol, cannabidiol, cannabinol, JWH018, JWH-073, AM2201, cannabis, dronabinol. 


\section{ABSTRACT}

Exogenous cannabinoids are structurally and pharmacologically diverse compounds that are widely used. The purpose of this systematic review is to summarize the data characterizing the potential for these compounds to act as substrates, inhibitors, or inducers of human drug metabolizing enzymes, with the aim of clarifying the significance of these properties in clinical care and drug interactions. In vitro data were identified that characterize cytochrome P-450 (CYP-450) enzymes as potential significant contributors to the primary metabolism of several exogenous cannabinoids: tetrahydrocannabinol (THC; CYPs 2C9, 3A4); cannabidiol (CBD; CYPs 2C19, 3A4); cannabinol (CBN; CYPs 2C9, 3A4); JWH-018 (CYPs 1A2, 2C9); and AM2201 (CYPs 1A2, 2C9). CYP-450 enzymes may also contribute to the secondary metabolism of THC, and UDP-glucuronosyltransferases have been identified as capable of catalyzing both primary (CBD, CBN) and secondary (THC, JWH-018, JWH-073) cannabinoid metabolism. Clinical pharmacogenetic data further support CYP2C9 as a significant contributor to THC metabolism, and a pharmacokinetic interaction study using ketoconazole with oromucosal cannabis extract further supports CYP3A4 as a significant metabolic pathway for THC and CBD. However, the absence of interaction between CBD from oromucosal cannabis extract with omeprazole suggests a less significant role of CYP2C19 in CBD metabolism. Studies of THC, CBD, and CBN inhibition and induction of major human CYP-450 isoforms generally reflect a low risk of clinically significant drug interactions with most use, but specific human data are lacking. Smoked cannabis herb (marijuana) likely induces CYP1A2 mediated theophylline metabolism, although the role of cannabinoids specifically in eliciting this effect is questionable.

\section{INTRODUCTION}

Cannabinoids are structurally diverse chemicals capable of exerting a broad range of pharmacologic effects. (Ashton, 2001; Ben Amar, 2006; ElSohly and Slade, 2005; Fattore and Fratta, 2011; Mehmedic et al., 2010; Pacher et al., 2006) Historically, the known cannabinoids were a group of related C21 terpenophenolic compounds and their biologic derivatives - the so-called "phytocannabinoids" - found in plants of the Cannabis genus, including Cannabis sativa, Cannabis indica, and Cannabis ruderalis. Today, the term 
"cannabinoid" is also used to refer to synthetic analogs of these compounds, many of which have no known natural source, as well as endogenous cannabinoid receptor ligands such as anandamide and 2arachidonoylglycerol.(ElSohly and Slade, 2005; Fattore and Fratta, 2011; Pacher et al., 2006)

Exogenous cannabinoids are widely consumed, in a variety of forms. Cannabinoid-rich preparations of cannabis, either in herb (i.e. marijuana) or resin form, are used by an estimated 2.6-5.0\% of the world population.(UNODC, 2012) Cannabinoid containing pharmaceutical products, either containing natural cannabis extracts (Sativex®, GW Pharmaceuticals) or the synthetic cannabinoids dronabinol ([-] $\Delta^{9-}$ tetrahydrocannabinol [THC]) or nabilone, are available for medical use in several countries (see U.S., Canada, and U.K. product information at http://www.accessdata.fda.gov/scripts/cder/ob/default.cfm, http://www.medicines.org.uk/emc/, and http://webprod5.hc-sc.gc.ca/dpd-bdpp/index-eng.jsp, respectively).(Hazecamp et al., 2013) Some synthetic cannabinoids that fall outside historic regulations in most countries are also included in herbal products marketed for recreational use.(Dresen et al., 2010; Fattore and Fratta, 2011)

The pharmacologic effects of most known cannabinoids have not been characterized in detail, although based on available data these effects may differ substantially between even very closely related compounds (e.g., THC and cannabidiol [CBD]).(Pertwee, 1997; Pertwee et al., 2010) Potential sites of action of different cannabinoids include G-protein coupled receptors (e.g. CB1 or CB2 cannabinoid, opioid, muscarinic, many others), ligand-gated ion channels (e.g. nicotinic, serotonin, glycine), other ion channels (e.g. calcium, potassium, sodium), nuclear receptors (e.g. peroxisome proliferator-activated receptors), and other targets.(Pertwee, 1997; Pertwee et al., 2010) Reported clinical effects of cannabinoids and cannabinoidcontaining products are accordingly broad, and may include analgesic, antiemetic, antispasmodic, appetitestimulating, concentration-diminishing, derealization, dizziness, dysphoric, euphoric, hallucinogenic, muscle relaxant, postural hypotensive, sedative, tachycardic, xerostomic, and numerous other effects.(Ashton, 2001; Ben Amar, 2006) 
Given the widespread availability and use of cannabinoids in different forms, and their potential to exert clinically significant pharmacologic actions, serious attention is owed to their metabolic fate and effects. The record of these characteristics, however, spans a long history of study that began shortly after the identification of THC as a major psychoactive constituent of cannabis in 1964.(Gaoni and Mechoulam, 1964) The purpose of this review is to summarize the data characterizing the potential for exogenous cannabinoids to act as substrates, inhibitors, or inducers of human drug metabolizing enzymes, with the aim of clarifying the significance of these properties in clinical care and drug interactions.

\section{METHODS}

A literature search was conducted of all PubMed (1948-September 2013) indexed articles pairing any included cannabinoid term with any included enzyme and associated drug term (both lists below). English language and human species limits were applied. Titles and abstracts of articles were screened for inclusion. Eligible studies investigated the effects of human drug metabolizing enzymes on exogenous cannabinoids, cannabinoid-containing products and extracts, cannabinoid derivatives, and cannabinoid metabolites, or the effects of these substances on the expression or activity of the enzymes. Data specific to known enzyme isoforms were included in place of more general data when both were available. In vivo and ex vivo human studies were also included when they investigated reactions specific to enzymes of interest, or described pharmacokinetic interactions involving the cytochrome P-450 (CYP-450) related drugs and reactions described below. References cited by included reports were reviewed for additional relevant information, as were prescribing information and summaries of product characteristics for U.S. and U.K. approved cannabinoid products.

Searches, reference screening, and data extraction were carried out in duplicate, by both authors independently. Eligible studies were assessed using a standard form characterizing study methods, study population (if applicable), compounds and enzymes investigated, and the direction and magnitude of observed effects. 


\section{Cannabinoids}

The following cannabinoid related search terms were included: tetrahydrocannabinol, cannabidiol, cannabinol, cannabichromene, cannabigerol, and tetrahydrocannabivarin (some of the more common phytocannabinoids found on initial review of the topic);(Mehmedic et al., 2010) dronabinol and nabilone (U.S. approved synthetic cannabinoids); and the general terms cannabinoid (to capture other cannabinoids not explicitly included), cannabis, hash, hashish, and marijuana.

\section{Enzyme and associated drug terms}

The following terms were used for major drug metabolizing enzyme types: enzymes and coenzymes; cytochrome p-450; glucuronosyltransferase; dehydrogenase; sulfotransferase; acetyltransferase; acyltransferase; methyltransferase; transferase; monooxygenase; hydrolase; oxidoreductase; reductase; oxidase; peroxidase; esterase; cholinesterase; and amidase. Additionally, terms for drugs and reactions corresponding to the substrates (preferred, acceptable, sensitive, or not specified), inhibitors (preferred, acceptable, strong, or not specified), and inducers (strong or not specified) of CYP-450 isoforms listed by the U.S. Food and Drug Administration Drug Development and Drug Interactions: Table of Substrates, Inhibitors and Inducers were included, as summarized in Table 1

(http://www.fda.gov/Drugs/DevelopmentApprovalProcess/DevelopmentResources/DrugInteractionsLabeli ng/ucm093664.htm, accessed September 20, 2013).

Following the PubMed search and review, two searches of Google Scholar (http://scholar.google.com/) were conducted applying the same inclusion and exclusion criteria. The terms "cannabinoid metabolism" and "human cannabinoid metabolism" were used, and each search was terminated the first time 100 consecutive results were returned that did not meet inclusion criteria.

\section{RESULTS}

A total of 6094 results were generated through the initial PubMed search, which reduced to 2992 after human and English limits were applied. From these, 29 publications meeting inclusion criteria were 
identified. A further six studies did not meet inclusion criteria but are included in the Results tables and/or Discussion based on their potential relevance to the topic or search terms applied. The Google Scholar search yielded no additional studies meeting inclusion criteria.

In vitro and ex vivo data

Figures 1 and 2 summarize in vitro data describing potential metabolic pathways of cannabinoids, derivatives, and metabolites in vitro. Figure 3 depicts the chemical structure of the parent cannabinoids for which data were found and included. Based on studies to date, (CYP-450) 2C9 and 3A4 are predicted to play major roles in the primary metabolism of THC.(Bland et al., 2005; Bornheim et al., 1992; Richardson et al., 1995; Watanabe et al., 1995; Watanabe et al., 2007) Secondary THC metabolism may occur via several pathways: 7-OH $\Delta^{8}$-THC by CYP-450 isoforms (primarily 3A4);(Matsunaga et al., 2000) 11-OH- $\Delta^{9}-\mathrm{THC}$ and 11-nor-9-carboxy- $\Delta^{9}$-THC (THC-COOH) by several UGT isoforms;(Mazur et al., 2009) 11-oxo- $\Delta^{8}$-THC by CYP450 isoforms (primarily 2C9);(Watanabe et al., 2002) and some epoxide metabolites of $\Delta^{8}$-THC by epoxide hydrolase.(Yamamoto et al., 1984) THC metabolic findings are generally consistent across overlapping studies, despite variability in the specific form of THC used $\left(\Delta^{8}, \Delta^{9}\right.$, or plant-extracted mixed isomers).

Cannabinol (CBN) is also predicted to undergo significant metabolism via CYPs $2 \mathrm{C} 9$ and 3A4,(Watanabe et al., 1995; Watanabe et al., 2007) and CBD via CYPs 2C19 and 3A4.(Jiang et al., 2011) Both CBN and CBD may also be directly glucuronidated by several UGT isoforms.(Mazur et al., 2009) No studies of the secondary metabolism of CBN and CBD were identified.

Two synthetic cannabinoids, JWH-018 and AM2201, are predicted to be metabolized primarily by CYP1A2 and 2C9.(Chimalakonda et al., 2012) JWH-018 and JWH-073, the latter also a synthetic cannabinoid, were not directly glucuronidated by several studied UGT isoforms, while most investigated metabolites were conjugated by multiple isoforms.(Chimalakonda et al., 2011) 
Table 2 summarizes the available data describing inhibitory potencies of THC, CBD, and CBN at CYP- 450 isoforms.(Roth et al., 2001; Yamaori et al., 2011a; Yamaori et al., 2012; Yamaori et al., 2010; Yamaori et al., 2011b; Yamaori et al., 2011c) One additional study identified some potential for CBD to inhibit UGTs $1 \mathrm{~A} 9$ and 2B7, for CBN to inhibit UGT1A9, and for CBN to possibly activate UGT2B7, all based on the impact of these compounds on ethanol glucuronidation by recombinant isoforms.(Al Saabi et al., 2013) No investigations were identified that specifically evaluated potential enzyme activation or induction effects of cannabinoids. One study identified a small dose-dependent activation of phenytoin hydroxylation in human liver microsomes in the presence of THC, 11-OH THC, or THC-COOH;(Bland et al., 2005) however, a study in human hepatocytes summarized in the U.K. Summary of Product Characteristics (SPC) for oromucosal cannabis extract (Sativex®, 7/2012) found no relevant induction of CYPs 1A2, 2C9, 2C19, or 3A4 at concentrations of up to $1 \mu \mathrm{M}$ of a $1: 1 \% \mathrm{v} / \mathrm{v}$ THC botanical drug substance and CBD botanical drug substance.

In studies of monoamine oxidase (MAO) function: THC isomers and CBD exerted no or minimal impact on platelet MAO activity ex vivo (the greatest inhibitory effect was exerted by $\Delta^{9}-\mathrm{THC}$, with Ki $7.8 \mu \mathrm{M}$ );(Mazor et al., 1982) marijuana had no impact on ex vivo platelet MAO function in the four hours following smoking;(Stillman et al., 1978) and THC and CBD exerted little or no inhibition of liver or brain MAO activity in vitro, although some cannabis extract components may inhibit particularly the MAO-B isoform.(Schurr and Rigor, 1984) In long-term cannabis users, cannabis smoking did not affect ex vivo plasma dopamine $\beta$ hydroxylase activity acutely, and a 3 day abstinence from cannabis was associated with a $<10 \%$ increase compared to baseline activity.(Markianos and Stefanis, 1982) Finally, a cannabis extract with unknown cannabinoid content had no impact on red blood cell acetylcholinesterase activity in vitro, and a study found similar baseline and 30-60 min post-smoking ex vivo serum acetylcholinesterase activity in regular hashish users compared to tobacco users.(Coutselinis and Michalodimitrakis, 1981; Srivastava et al., 2012)

\section{Clinical data}

Published clinical studies meeting inclusion criteria are summarized in Table 3. The pharmacogenetic study by Sachse-Seeboth et al. (2009) found that THC exposure increased and THC-COOH exposure decreased 
across CYP2C9 genotypes ordered from the expected highest function * $1 /{ }^{*} 1$ to the lowest function * $3 / * 3$. THC area under the concentrations-time curve (AUC) was approximately 3 fold greater in a small sample of CYP2C $9 * 3 / * 3$ carriers compared to $* 1 / * 1$ carriers. CYP3A5 variants in this study were associated with no or minimal differences in THC pharmacokinetic variables.

In a clinical study summarized in the U.K. SPC for oromucosal cannabis extract, coadministration of ketoconazole increased the maximum concentration (Cmax) and AUC of THC by 1.2 and 1.8 fold, respectively, those of 11-OH-THC by 3 and 3.6 fold, respectively, and those of CBD each by 2 fold (Sativex® U.K. SPC 7/2012). The SPC also summarizes a study in which rifampin coadministration decreased the Cmax and AUC of THC by $40 \%$ and $20 \%$, respectively, those of $11-0 \mathrm{H}-\mathrm{THC}$ by $85 \%$ and $87 \%$, respectively, and those of CBD by $50 \%$ and $60 \%$, respectively. Coadministration with omeprazole, in contrast, caused no significant change in THC, 11-OH-THC, or CBD pharmacokinetic variables.

Oral THC and smoked marijuana did not increase indinavir exposure in a clinical study.(Kosel et al., 2002)

Two studies reported a $42-48 \%$ higher average estimated theophylline clearance in more frequent marijuana smokers ( $\geq 2$ joint/wk) compared to non-users.(Jusko et al., 1979; Jusko et al., 1978) These effects were not seen in lower exposure groups (<1 joint/wk).(Gardner et al., 1983; Jusko et al., 1979)

\section{DISCUSSION}

\section{Metabolic pathways}

Several in vitro studies were identified that characterize different effects of human drug metabolizing enzymes on cannabinoids and their metabolites. In particular, significant metabolism via specific CYP-450 isoforms is expected for THC (CYPs 2C9, 3A4), CBD (CYPs 2C19, 3A4) CBN (CYPs 2C9, 3A4), JWH-018 (CYPs 1A2, 2C9), and AM2201 (CYPs 1A2, 2C9) based on these data. CYP-450 enzymes may also contribute to secondary metabolism of THC, and UGTs have been identified as capable of catalyzing both primary (CBD, CBN) and secondary (THC, JWH-018, JWH-073) metabolism of some cannabinoids. 
Increases in THC and CBD exposure seen when ketoconazole was coadministered with oromucosal cannabis extract support CYP3A4 as a substantial contributor to metabolism of these compounds (Sativex® U.K. SPC 7/2012). The CYP2C9 dependent metabolism of THC is supported by clinical data indicating a 2-3 fold increase in THC exposure in individuals carrying genetic variants associated with diminished CYP2C9 function.(Sachse-Seeboth et al., 2009) The significance of CYP2C19 to the clearance of CBD, in contrast, was not supported by the clinical study with omeprazole (Sativex® U.K. SPC 7/2012). Together, these data suggest a potential for clinically meaningful elevations in THC exposure in individuals with diminished CYP2C9 or 3A4 function, and in CBD exposure in individuals with diminished CYP3A4 function. Further, changes in THC and CBD exposure with rifampin suggest a potential for strong induction of these pathways to cause meaningful reductions in THC and CBD exposure.

\section{Inhibition and induction characteristics}

Inhibitory constants and/or half maximal inhibitory concentration values of THC, CBD, and CBN at studied CYP-450 isoforms are generally well below the expected systemic concentrations of these cannabinoids with most use (Marinol® U.S. prescribing information 6/2006; Sativex® U.K. SPC 7/2012).(Huestis, 2007; Johansson et al., 1987; Ohlsson et al., 1986; Ohlsson et al., 1982) Further, regular dronabinol use or marijuana smoking had minimal impact on indinavir pharmacokinetic variables, suggesting a low clinical impact on CYP3A4 function.(Kosel et al., 2002) Nonetheless, given the lack of inhibition data at several CYP450 isoforms, the wide variability in cannabinoid product content and dosing, and the inherent imprecision of using concentration/inhibition potency ratios to predict in vivo drug interaction potential, clinically significant inhibitory effects cannot be ruled out entirely. Notably, the only studies found during this review that suggested clinically evident inhibition of CYP-450s in humans did not meet inclusion criteria, and suggested some possible weak CYP2C inhibition by CBD based on decreases in hexobarbital clearance and 11hydroxylation of THC with concomitant CBD use.(Benowitz et al., 1980; Nadulski et al., 2005)

Although in vitro data suggest a lack of relevant induction of CYPs 1A2, 2C9, 2C19, and 3A4 by plant-extracted THC and CBD, marijuana smoking appears to induce theophylline clearance. CYP1A2 is likely the dominant 
isoform affected based on relative changes seen in theophylline (a substrate of CYP1A2 and 3A4) and indinavir (primarily a CYP3A4 substrate) exposure.(Jusko et al., 1979; Kosel et al., 2002) The connection of this effect to cannabinoids themselves, however, is questionable given the similar effects seen with tobacco smoking, the lack of evidence of induction from studies using non-smoked cannabinoid preparations, and the aforementioned in vitro data (Sativex® U.K. SPC 7/2012).

\section{Data not meeting inclusion criteria}

Two studies in Table 3 did not meet inclusion criteria, but are included as they may provide additional insight into the specific pharmacokinetic effects described above.(Chetty et al., 1994; Engels et al., 2007) In a population pharmacokinetic analysis, self-reported regular cannabis use was associated with a $50 \%$ increase in estimated chlorpromazine clearance.(Chetty et al., 1994) This may reflect net CYP1A2 induction by nonTHC components of smoked marijuana, consistent with results seen with theophylline. Study data indicating a lack of impact of dronabinol on nelfinavir exposure, or of a marijuana tea on irinotecan or docetaxel exposure, provide additional evidence for a low impact of non-smoked cannabinoid preparations on CYP3A4 mediated metabolism.(Engels et al., 2007; Kosel et al., 2002)

Although this review did not aim to comprehensively characterize transport phenomena related to cannabinoids, some potential transporter-related effects were identified. In vitro data were found that suggest: THC inhibition of the ATP binding cassette $(\mathrm{ABC})$ family transporters P-glycoprotein (P-gp, $A B C B 1$ ) and breast cancer resistance protein (BCRP, ABCG2);(Tournier et al., 2010) CBN inhibition of P-gp, although THC, THC-COOH and CBN were not identified as significant inhibitors in this study; (Zhu et al., 2006) and THC, CBN, and CBD inhibition of the BCRP and the ABC transporter multidrug resistance-related protein 1 (MRP1, ABCC1).(Holland et al., 2008; Holland et al., 2007)

\section{Limitations}

Some important potential limitations of the methodology of this review should be noted. First, the search strategy, while broad, gives no guarantee that the results are totally comprehensive. The combination of 
PubMed and Google Scholar was chosen based on some complementary properties, but may not cover all potential data sources.(Shultz, 2007) Second, it is likely that some additional support for enzyme-related effects described in this review exist in case reports and studies investigating less common probe drugs or pathways. Two such studies were identified and appended to Table 3, although others may exist. Finally, the exclusion of non-human data may also be viewed as a limitation. However, non-human data were felt to be of at best secondary importance in achieving the primary goal of assessing the potential significance of enzyme related data to human pharmacotherapy.

\section{Conclusion}

In conclusion, significant findings relating to the metabolic fate and effects of exogenous cannabinoids have accumulated for over 30 years, yet significant gaps in the data remain. In particular, few in vitro findings have been validated in human studies, except those pertaining to the major metabolic pathways of THC and CBD. The individual who uses cannabinoids, especially those other than THC or CBD, therefore assumes an unclear risk related to metabolic drug interactions. At present, general caution appears warranted particularly when function of the major oxidative cannabinoid metabolic pathways is substantially increased or decreased. Exposure and systemic effects of CYP1A2 substrates may be decreased in individuals who smoke marijuana, although the connection of this effect to the cannabinoids specifically is questionable. Interactions involving cannabinoids are expected to vary considerably in their clinical significance given the wide variability in products, doses, routes of administration, populations using cannabinoids, and other factors.

\section{ACKNOWLEDGEMENTS}

None

\section{DECLARATION OF INTEREST}

The authors report no declarations of interest. 


\section{REFERENCES}

Al Saabi A, Allorge D, Sauvage FL, Tournel G, Gaulier JM, Marquet P, Picard N. (2013). Involvement of UDPglucuronosyltransferases UGT1A9 and UGT2B7 in ethanol glucuronidation, and interactions with common drugs of abuse. Drug Metab Dispos, 41, 568-74.

Ashton CH. (2001). Pharmacology and effects of cannabis: a brief review. Br J Psychiatry, 178, 101-6.

Ben Amar M. (2006). Cannabinoids in medicine: A review of their therapeutic potential. J Ethnopharmacol, $105,1-25$.

Benowitz NL, Nguyen TL, Jones RT, Herning RI, Bachman J. (1980). Metabolic and psychophysiologic studies of cannabidiol-hexobarbital interaction. Clin Pharmacol Ther, 28, 115-20.

Bland TM, Haining RL, Tracy TS, Callery PS. (2005). CYP2C-catalyzed delta9-tetrahydrocannabinol metabolism: kinetics, pharmacogenetics and interaction with phenytoin. Biochem Pharmacol, 70, 1096-103.

Bornheim LM, Lasker JM, Raucy JL. (1992). Human hepatic microsomal metabolism of delta 1tetrahydrocannabinol. Drug Metab Dispos, 20, 241-6.

Chetty M, Miller R, Moodley SV. (1994). Smoking and body weight influence the clearance of chlorpromazine. Eur J Clin Pharmacol, 46, 523-6.

Chimalakonda KC, Bratton SM, Le VH, Yiew KH, Dineva A, Moran CL, James LP, Moran JH, Radominska-Pandya A. (2011). Conjugation of synthetic cannabinoids JWH-018 and JWH-073, metabolites by human UDPglucuronosyltransferases. Drug Metab Dispos, 39, 1967-76.

Chimalakonda KC, Seely KA, Bratton SM, Brents LK, Moran CL, Endres GW, James LP, Hollenberg PF, Prather PL, Radominska-Pandya A, Moran JH. (2012). Cytochrome P450-mediated oxidative metabolism of abused synthetic cannabinoids found in K2/Spice: identification of novel cannabinoid receptor ligands. Drug Metab Dispos, 40, 2174-84.

Coutselinis A, Michalodimitrakis M. (1981). Acetylcholinesterase activity after hashish smoking. Clin Toxicol, 18, 385-7.

Dresen S, Ferreiros N, Putz M, Westphal F, Zimmermann R, Auwarter V. (2010). Monitoring of herbal mixtures potentially containing synthetic cannabinoids as psychoactive compounds. J Mass Spectrom, 45, 1186-94.

ElSohly MA, Slade D. (2005). Chemical constituents of marijuana: the complex mixture of natural cannabinoids. Life Sci, 78, 539-48.

Engels FK, de Jong FA, Sparreboom A, Mathot RA, Loos WJ, Kitzen JJ, de Bruijn P, Verweij J, Mathijssen RH. (2007). Medicinal cannabis does not influence the clinical pharmacokinetics of irinotecan and docetaxel. Oncologist, 12, 291-300.

Fattore L, Fratta W. (2011). Beyond THC: The New Generation of Cannabinoid Designer Drugs. Front Behav Neurosci, 5, 60.

Gaoni Y, Mechoulam R. (1964). Isolation, Structure, and Partial Synthesis of an Active Constituent of Hashish. Journal of the American Chemical Society, 86, 1646-7.

Gardner MJ, Tornatore KM, Jusko WJ, Kanarkowski R. (1983). Effects of tobacco smoking and oral contraceptive use on theophylline disposition. Br J Clin Pharmacol, 16, 271-80.

Hazecamp A, Ware MA, Muller-Vahl KR, Abrams D, Grotenhermen F. (2013). The medicinal use of cannabis and cannabinoids-An international cross-sectional survey on administration forms. J Psychoactive Drugs, 45, 199-219.

Holland ML, Allen JD, Arnold JC. (2008). Interaction of plant cannabinoids with the multidrug transporter ABCC1 (MRP1). Eur J Pharmacol, 591, 128-31.

Holland ML, Lau DT, Allen JD, Arnold JC. (2007). The multidrug transporter ABCG2 (BCRP) is inhibited by plant-derived cannabinoids. Br J Pharmacol, 152, 815-24.

Huestis MA. (2007). Human cannabinoid pharmacokinetics. Chem Biodivers, 4, 1770-804.

Jiang R, Yamaori S, Takeda S, Yamamoto I, Watanabe K. (2011). Identification of cytochrome P450 enzymes responsible for metabolism of cannabidiol by human liver microsomes. Life Sci, 89, 165-70.

Johansson E, Ohlsson A, Lindgren JE, Agurell S, Gillespie H, Hollister LE. (1987). Single-dose kinetics of deuterium-labelled cannabinol in man after intravenous administration and smoking. Biomed Environ Mass Spectrom, 14, 495-9. 
Jusko WJ, Gardner MJ, Mangione A, Schentag JJ, Koup JR, Vance JW. (1979). Factors affecting theophylline clearances: age, tobacco, marijuana, cirrhosis, congestive heart failure, obesity, oral contraceptives, benzodiazepines, barbiturates, and ethanol. J Pharm Sci, 68, 1358-66.

Jusko WJ, Schentag JJ, Clark JH, Gardner M, Yurchak AM. (1978). Enhanced biotransformation of theophylline in marihuana and tobacco smokers. Clin Pharmacol Ther, 24, 405-10.

Kosel BW, Aweeka FT, Benowitz NL, Shade SB, Hilton JF, Lizak PS, Abrams DI. (2002). The effects of cannabinoids on the pharmacokinetics of indinavir and nelfinavir. AIDS, 16, 543-50.

Markianos M, Stefanis C. (1982). Effects of acute cannabis use and short-term deprivation on plasma prolactin and dopamine-beta-hydroxylase in long-term users. Drug Alcohol Depend, 9, 251-5.

Matsunaga T, Kishi N, Higuchi S, Watanabe K, Ohshima T, Yamamoto I. (2000). CYP3A4 is a major isoform responsible for oxidation of 7-hydroxy-Delta(8)-tetrahydrocannabinol to 7-oxo-delta(8)tetrahydrocannabinol in human liver microsomes. Drug Metab Dispos, 28, 1291-6.

Mazor M, Dvilansky A, Aharon M, Lazarovitz Z, Nathan I. (1982). Effect of cannabinoids on the activity of monoamine oxidase in normal human platelets. Arch Int Physiol Biochim, 90, 15-20.

Mazur A, Lichti CF, Prather PL, Zielinska AK, Bratton SM, Gallus-Zawada A, Finel M, Miller GP, RadominskaPandya A, Moran JH. (2009). Characterization of human hepatic and extrahepatic UDPglucuronosyltransferase enzymes involved in the metabolism of classic cannabinoids. Drug Metab Dispos, 37, 1496-504.

Mehmedic Z, Chandra S, Slade D, Denham H, Foster S, Patel AS, Ross SA, Khan IA, ElSohly MA. (2010). Potency trends of Delta9-THC and other cannabinoids in confiscated cannabis preparations from 1993 to 2008. J Forensic Sci, 55, 1209-17.

Nadulski T, Pragst F, Weinberg G, Roser P, Schnelle M, Fronk EM, Stadelmann AM. (2005). Randomized, double-blind, placebo-controlled study about the effects of cannabidiol (CBD) on the pharmacokinetics of Delta9-tetrahydrocannabinol (THC) after oral application of THC verses standardized cannabis extract. Ther Drug Monit, 27, 799-810.

Ohlsson A, Lindgren JE, Andersson S, Agurell S, Gillespie H, Hollister LE. (1986). Single-dose kinetics of deuterium-labelled cannabidiol in man after smoking and intravenous administration. Biomed Environ Mass Spectrom, 13, 77-83.

Ohlsson A, Lindgren JE, Wahlen A, Agurell S, Hollister LE, Gillespie HK. (1982). Single dose kinetics of deuterium labelled delta 1-tetrahydrocannabinol in heavy and light cannabis users. Biomed Mass Spectrom, 9, 6-10.

Pacher P, Batkai S, Kunos G. (2006). The endocannabinoid system as an emerging target of pharmacotherapy. Pharmacol Rev, 58, 389-462.

Pertwee RG. (1997). Pharmacology of cannabinoid CB1 and CB2 receptors. Pharmacol Ther, 74, 129-80.

Pertwee RG, Howlett AC, Abood ME, Alexander SP, Di Marzo V, Elphick MR, Greasley PJ, Hansen HS, Kunos G, Mackie K, Mechoulam R, Ross RA. (2010). International Union of Basic and Clinical Pharmacology. LXXIX. Cannabinoid receptors and their ligands: beyond CB(1) and CB(2). Pharmacol Rev, 62, 588631.

Richardson TH, Jung F, Griffin KJ, Wester M, Raucy JL, Kemper B, Bornheim LM, Hassett C, Omiecinski CJ, Johnson EF. (1995). A universal approach to the expression of human and rabbit cytochrome P450s of the 2C subfamily in Escherichia coli. Arch Biochem Biophys, 323, 87-96.

Roth MD, Marques-Magallanes JA, Yuan M, Sun W, Tashkin DP, Hankinson O. (2001). Induction and regulation of the carcinogen-metabolizing enzyme CYP1A1 by marijuana smoke and delta (9)tetrahydrocannabinol. Am J Respir Cell Mol Biol, 24, 339-44.

Sachse-Seeboth C, Pfeil J, Sehrt D, Meineke I, Tzvetkov M, Bruns E, Poser W, Vormfelde SV, Brockmoller J. (2009). Interindividual variation in the pharmacokinetics of Delta9-tetrahydrocannabinol as related to genetic polymorphisms in CYP2C9. Clin Pharmacol Ther, 85, 273-6.

Schurr A, Rigor BM. (1984). Cannabis extract, but not delta 1-tetrahydrocannabinol, inhibits human brain and liver monoamine oxidase. Gen Pharmacol, 15, 171-4.

Shultz M. (2007). Comparing test searches in PubMed and Google Scholar. J Med Libr Assoc, 95, 442-5.

Srivastava N, Sharma RK, Singh N, Sharma B. (2012). Acetylcholinesterase from human erythrocytes membrane: a screen for evaluating the activity of some traditional plant extracts. Cell Mol Biol (Noisyle-grand), 58, 160-9.

Stillman RC, Wyatt RJ, Murphy DL, Rauscher FP. (1978). Low platelet monoamine oxidase activity and chronic marijuana use. Life Sci, 23, 1577-81. 
Tournier N, Chevillard L, Megarbane B, Pirnay S, Scherrmann JM, Decleves X. (2010). Interaction of drugs of abuse and maintenance treatments with human P-glycoprotein (ABCB1) and breast cancer resistance protein (ABCG2). Int J Neuropsychopharmacol, 13, 905-15.

UNODC (2012) United Nations Office on Drugs and Crime. World Drug Report 2012, United Nations, New York, NY.

Watanabe K, Matsunaga T, Kimura T, Funahashi T, Funae Y, Ohshima T, Yamamoto I. (2002). Major cytochrome P450 enzymes responsible for microsomal aldehyde oxygenation of 11-oxo-Delta8tetrahydrocannabinol and 9-anthraldehyde in human liver. Drug Metab Pharmacokinet, 17, 516-21.

Watanabe K, Matsunaga T, Yamamoto I, Funae Y, Yoshimura H. (1995). Involvement of CYP2C in the metabolism of cannabinoids by human hepatic microsomes from an old woman. Biol Pharm Bull, 18, 1138-41.

Watanabe K, Yamaori S, Funahashi T, Kimura T, Yamamoto I. (2007). Cytochrome P450 enzymes involved in the metabolism of tetrahydrocannabinols and cannabinol by human hepatic microsomes. Life Sci, 80, 1415-9.

Yamamoto I, Narimatsu S, Shimonishi T, Watanabe K, Yoshimura H. (1984). Difference in epoxides formation and their further metabolism between delta 9- and delta 8-tetrahydrocannabinols by human liver microsomes. J Pharmacobiodyn, 7, 254-62.

Yamaori S, Ebisawa J, Okushima Y, Yamamoto I, Watanabe K. (2011a). Potent inhibition of human cytochrome P450 3A isoforms by cannabidiol: role of phenolic hydroxyl groups in the resorcinol moiety. Life Sci, 88, 730-6.

Yamaori S, Koeda K, Kushihara M, Hada Y, Yamamoto I, Watanabe K. (2012). Comparison in the in vitro inhibitory effects of major phytocannabinoids and polycyclic aromatic hydrocarbons contained in marijuana smoke on cytochrome P450 2C9 activity. Drug Metab Pharmacokinet, 27, 294-300.

Yamaori S, Kushihara M, Yamamoto I, Watanabe K. (2010). Characterization of major phytocannabinoids, cannabidiol and cannabinol, as isoform-selective and potent inhibitors of human CYP1 enzymes. Biochem Pharmacol, 79, 1691-8.

Yamaori S, Maeda C, Yamamoto I, Watanabe K. (2011b). Differential inhibition of human cytochrome P450 2A6 and 2B6 by major phytocannabinoids. Forensic Toxicol, 29, 117-24.

Yamaori S, Okamoto Y, Yamamoto I, Watanabe K. (2011c). Cannabidiol, a major phytocannabinoid, as a potent atypical inhibitor for CYP2D6. Drug Metab Dispos, 39, 2049-56.

Zhu HJ, Wang JS, Markowitz JS, Donovan JL, Gibson BB, Gefroh HA, Devane CL. (2006). Characterization of Pglycoprotein inhibition by major cannabinoids from marijuana.J Pharmacol Exp Ther, 317, 850-7. 
Table 1: Search terms for substrates, inhibitors, and inducers of human CYP-450 enzymes in vitro and in vivo

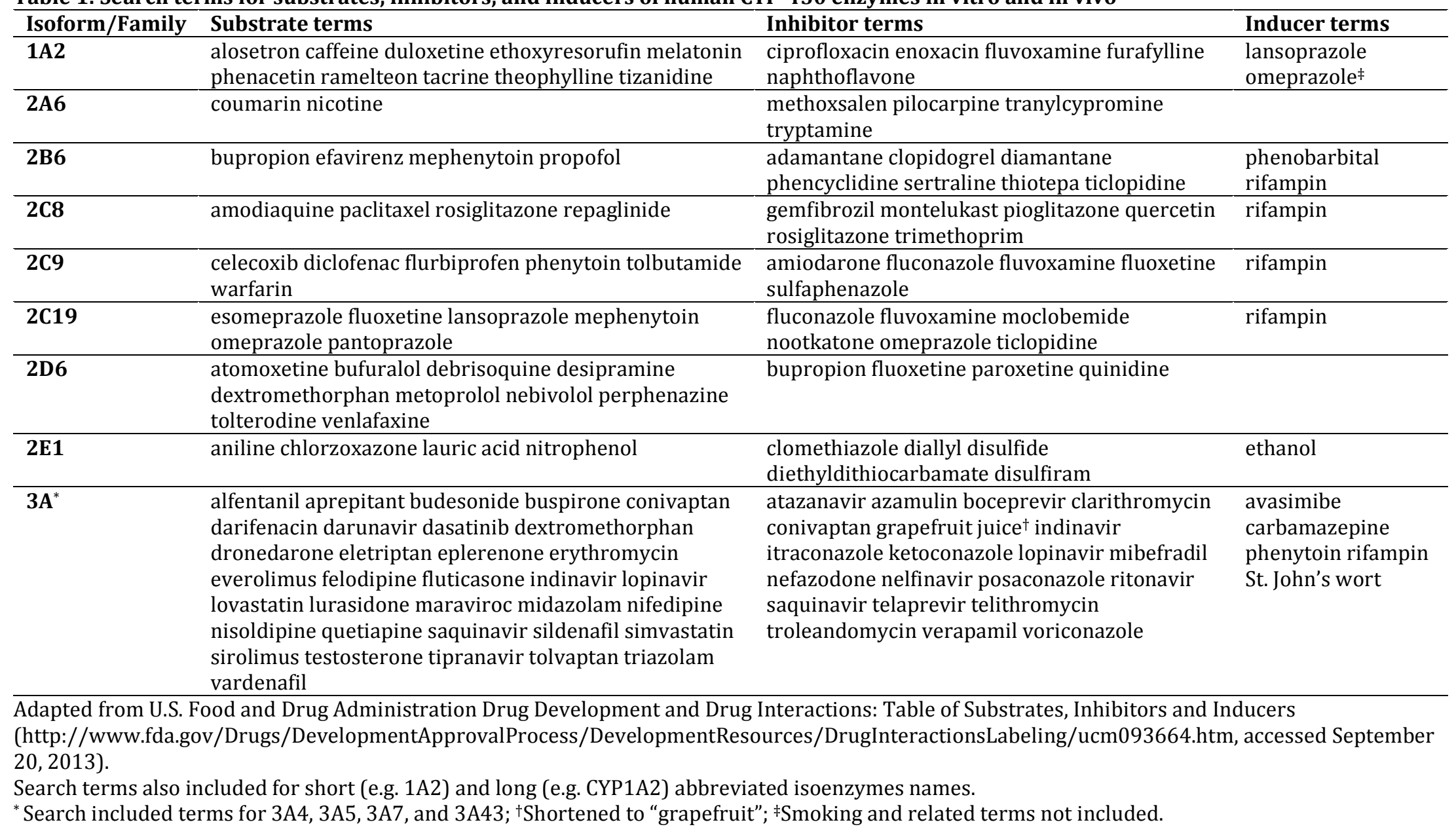


Table 2: Inhibition of human metabolic enzymes by exogenous cannabinoids in vitro.

\begin{tabular}{|c|c|c|c|c|c|c|c|c|c|c|}
\hline & \multicolumn{10}{|c|}{ CYP-450 isoform } \\
\hline & 1A1 & $1 \mathrm{~A} 2$ & 1B1 & $2 \mathrm{~A} 6$ & 2B6 & $2 \mathrm{C} 9$ & 2D6 & $3 \mathrm{~A} 4$ & $3 \mathrm{~A} 5$ & 3A7 \\
\hline$\Delta^{9}-\mathrm{THC}$ & $4.78 \mu \mathrm{M}^{*}$ & $7.54 \mu \mathrm{M}$ & $2.47 \mu \mathrm{M}$ & $28.9 \mu \mathrm{M}^{*}$ & $2.81 \mu \mathrm{M}$ & $0.94-1.50 \mu \mathrm{M}$ & $17.1-22.9 \mu \mathrm{M}^{\dagger}$ & $>50 \mu \mathrm{M}^{\dagger}$ & $35.6 \mu \mathrm{M}^{\dagger}$ & $30.3 \mu \mathrm{M}^{\dagger}$ \\
\hline CBD & $0.155 \mu \mathrm{M}^{*}$ & $2.69 \mu \mathrm{M}^{*}$ & $3.63 \mu \mathrm{M}^{*}$ & $55.0 \mu \mathrm{M}^{*}$ & $0.694 \mu \mathrm{M}$ & $0.95-9.88 \mu \mathrm{M}$ & $1.16-2.69 \mu \mathrm{M}^{\ddagger}$ & $1.00 \mu \mathrm{M}$ & $0.195 \mu \mathrm{M}$ & $12.3 \mu \mathrm{M}$ \\
\hline CBN & $0.541 \mu \mathrm{M}^{*}$ & $0.0790 \mu \mathrm{M}$ & $0.148 \mu \mathrm{M}$ & $39.8 \mu \mathrm{M}$ & $2.55 \mu \mathrm{M}$ & $0.88-1.29 \mu \mathrm{M}$ & $12.3-24.9 \mu \mathrm{M}^{\dagger}$ & $>50 \mu \mathrm{M}^{\dagger}$ & $>50 \mu \mathrm{M}^{\dagger}$ & $23.8 \mu \mathrm{M}^{\dagger}$ \\
\hline
\end{tabular}

Supporting data: (Roth et al., 2001; Yamaori et al., 2011a; Yamaori et al., 2012; Yamaori et al., 2010; Yamaori et al., 2011b; Yamaori et al., 2011c)

${ }^{*}$ Evidence of enzyme inactivation; †Half maximal inhibitory concentration (IC50). Other reported values are inhibition constants (K $\mathrm{K}_{\mathrm{i}}$; $\neq$ Evidence of timedependent inhibition, without further analysis.

Additional analyses in the cited references indicate: Inhibition of CYPs 2B6 ( $\left.\mathrm{K}_{\mathrm{i}} 1.29 \mu \mathrm{M}\right)$ and 2D6 (IC $\left.5010.2 \mu \mathrm{M}\right)$ by cannabidivarin; little or no

measurable inhibition of CYP2D6 by mono- and dimethylated CBD derivatives or several polycyclic aromatic hydrocarbons found in marijuana smoke;

little or no measurable inhibition of CYP2C9 by several polycyclic aromatic hydrocarbons found in marijuana smoke; and substantially lower inhibition potency of mono- and dimethylated CBD derivatives at CYPs 2A6, 2B6, and 3A compared to CBD. 
Table 3: Clinical studies reflecting potential CYP-450 isoform/family specific drug interaction potential of exogenous cannabinoids.

$\begin{array}{lllll}\text { Study } & \text { N } & \text { Population } & \text { Relevant } & \text { Pharmacokinetic Results }\end{array}$

(Sachse-

43 Healthy volunteer

Groups/Treatments

Suggestion

Seeboth et al nonsmokers age 18-65

All subjects given a single

Significant trends of greater THC, Significant increases in

2009)

years genotyped for

lower THC-COOH exposure (AUC,

THC exposure and

CYP2C9 * 1 *2, and *3,

CYP $3 A 5^{*} 1$ and $* 3$, and

Cmax, C24h) across ordered

CYP2C 9 types $\left(* 1 /{ }^{*} 1,{ }^{*} 1 /{ }^{*} 2,{ }^{*} 2 /{ }^{*} 2\right.$,

${ }^{*} 1 /{ }^{*} 3, * 2 /{ }^{*} 3, * 3 /{ }^{*} 3$ ). No similar

decreases in THC-COOH

SLC01B1 Asn130Asp and

trend in THC-OH pharmacokinetic

variables. Small group of $* 3 / * 3$

carriers $(\mathrm{N}=4)$ had $\sim 3$ fold greater

median THC AUC, $~ 70 \%$ lower

median THC-COOH AUC than *1/*1

carriers $(\mathrm{N}=19)$.

No or minor association between investigated $C Y P 3 A 5$ and $S L C O 1 B 1$ types and THC or metabolite PK.

\begin{tabular}{|c|c|c|c|}
\hline $\begin{array}{c}\text { (Kosel et al., } \\
2002)\end{array}$ & 28 & $\begin{array}{l}\text { Patients receiving } \\
\text { indinavir ( } 800 \text { mg q8h), } \\
\text { with experience smoking } \\
\text { marijuana but no } \\
\text { cannabinoids within } 30 \\
\text { days. }\end{array}$ & $\begin{array}{l}\text { Random assignment to one } \\
\text { of the following three times } \\
\text { daily, } 1 \mathrm{~h} \text { before meals for } \\
\text { 14 days: } \\
\text { - Placebo } \\
\text { - Marijuana cigarettes } \\
(3.95 \% \text { THC, as } \\
\text { tolerated) } \\
\text { - }- \text { - } \Delta^{9} \text {-THC (dronabinol, } \\
2.5 \text { mg orally) }\end{array}$ \\
\hline
\end{tabular}

Cmax, AUC, or Cmin between

baseline and 14 days, except $14 \%$

average decrease in indinavir

Cmax in marijuana arm.

generation possible with

low or diminished CYP2C9

function.

$2.5 \mathrm{mg}$ orally)

\begin{tabular}{cl}
\hline (Jusko et al., & $57 \quad \begin{array}{l}\text { Healthy volunteers age } \\
\text { 1978) }\end{array}$ \\
& who-47 years, including 7 \\
& twice weekly; final cohort \\
& average $\sim 4$ times/week) \\
& marijuana smoking, 7 who \\
& reported chronic \\
& marijuana and tobacco \\
& smoking, and 24 who \\
& reported smoking tobacco \\
& only. Average reported \\
\hline
\end{tabular}

Subjects all given a single 3- Compared to nonsmokers,

$5 \mathrm{mg}$ oral aminophylline

marijuana smokers had roughly

$42 \%$ greater estimated

theophylline clearance, similar to

tobacco smokers, while combined

tobacco and marijuana smokers

had roughly $79 \%$ greater

clearance.

Low net CYP3A4

inhibitory/induction

potential of marijuana

smoking and dronabinol

Parallel study $(\mathrm{N}=34)$

finding no significant

impact of the same

marijuana and dronabinol

regimens on nelfinavir

Cmax, Cmin, AUC, further

supports this conclusion.

Possible net induction of

theophylline metabolism

by marijuana smoking,

particularly with use of $\geq 2$

joint/wk. Taken with the

Kosel et al. (2002) findings,

CYP1A2 is the likely

primary pathway affected. 


\begin{tabular}{|c|c|c|c|c|c|}
\hline & & $\begin{array}{l}\text { tobacco consumption } 20- \\
25 \text { cigarettes/day among } \\
\text { tobacco smokers. }\end{array}$ & & & \\
\hline $\begin{array}{c}\text { (Jusko et al., } \\
1979)\end{array}$ & 200 & $\begin{array}{l}\text { Patients treated with } \\
\text { theophylline }(\mathrm{N}=100) \text { and } \\
\text { historic / literature } \\
\text { derived subjects given } \\
\text { theophylline }(\mathrm{N}=100) \text {, age } \\
<20 \text { to }>60 \text {, of whom } 9 \\
\text { reported marijuana use }<1 \\
\text { joint/wk, } 14 \text { reported } \\
\text { marijuana use } \geq 2 \\
\text { joint/wk. }\end{array}$ & $\begin{array}{l}\text { Theophylline clearance } \\
\text { estimated in all treated } \\
\text { patients based on } \\
\text { pharmacokinetic data, or } \\
\text { derived from previous } \\
\text { reports in } \\
\text { historic/literature subjects. }\end{array}$ & $\begin{array}{l}\text { Marijuana use } \geq 2 \text { joint/wk } \\
\text { associated with approximate } 48 \% \\
\text { greater average estimated } \\
\text { theophylline clearance, compared } \\
\text { to an average } 4 \% \text { decline with use } \\
<1 \text { joint/wk. }\end{array}$ & \\
\hline $\begin{array}{l}\text { (Gardner et } \\
\text { al., 1983) }\end{array}$ & 49 & $\begin{array}{l}\text { Healthy women age } 19-30 \\
\text { years, of whom } 16 \\
\text { reported marijuana use }<1 \\
\text { joint/wk and none } \\
\text { reported greater } \\
\text { marijuana use. }\end{array}$ & $\begin{array}{l}\text { Subjects all given a single } 4 \\
\mathrm{mg} / \mathrm{kg} \text { oral theophylline } \\
\text { dose. }\end{array}$ & $\begin{array}{l}\text { Marijuana use not associated with } \\
\text { significant differences in weight- } \\
\text { normalized theophylline plasma } \\
\text { clearance, controlled for caffeine } \\
\text { use, oral contraceptive use, } \\
\text { tobacco use, and other variables. }\end{array}$ & \\
\hline $\begin{array}{l}\text { (Mwenifumbo } \\
\text { et al., 2007) }\end{array}$ & 190 & $\begin{array}{l}\text { Healthy volunteers age } \\
20-59 \text { years, with at least } \\
3 \text { grandparents of black } \\
\text { African descent, not } \\
\text { receiving known enzyme- } \\
\text { inducing medications, of } \\
\text { whom } 68 \text { reported } \\
\text { marijuana use: } 1-4 \\
\text { joints/mo }(\mathrm{N}=21) ; 5-20 \\
\text { joints/mo }(\mathrm{N}=16) ; 24-56 \\
\text { joints/mo }(\mathrm{N}=16) ; \text { or } 60- \\
200 \text { joints/mo }(\mathrm{N}=15) .94 \\
\text { subjects reported smoking } \\
\text { tobacco. Only subjects } \\
\text { with } C Y P 2 A 6^{*} 1{ }^{*} 1 \\
\text { genotype included. }\end{array}$ & $\begin{array}{l}\text { Subjects all given a single } \\
\text { nicotine bitartrate dose ( } 4 \\
\text { mg nicotine base) following } \\
\text { a } 12 \mathrm{~h} \text { period of abstinence } \\
\text { from all smoking. }\end{array}$ & $\begin{array}{l}\text { 3'-hydroxycotinine/cotinine } \\
\text { concentration ratio } 270 \text { min after } \\
\text { dosing not significantly different } \\
\text { among marijuana use strata when } \\
\text { controlled for sex and tobacco } \\
\text { smoking status. Estimated } \\
\text { nicotine AUC in the } 360 \text { min after } \\
\text { dosing not significantly different } \\
\text { among marijuana use strata when } \\
\text { controlled for tobacco smoking } \\
\text { status. }\end{array}$ & $\begin{array}{l}\text { Low net CYP2A6 } \\
\text { inhibition/induction } \\
\text { potential of smoked } \\
\text { marijuana. }\end{array}$ \\
\hline \multicolumn{6}{|c|}{ Studies not meeting inclusion criteria } \\
\hline $\begin{array}{c}\text { (Chetty et al., } \\
\text { 1994) }\end{array}$ & 31 & $\begin{array}{l}\text { Inpatients with } \\
\text { schizophrenia age 16-45 } \\
\text { years initiating }\end{array}$ & $\begin{array}{l}\text { Population PK analysis of } \\
\text { therapeutic drug monitoring } \\
\text { data using chlorpromazine }\end{array}$ & $\begin{array}{l}\text { Cannabis use associated with 50\% } \\
\text { greater average estimated } \\
\text { chlorpromazine clearance, }\end{array}$ & $\begin{array}{l}\text { Possible additional support } \\
\text { for CYP1A2 induction by } \\
\text { marijuana smoking. }\end{array}$ \\
\hline
\end{tabular}




\begin{tabular}{|c|c|c|c|c|}
\hline & $\begin{array}{l}\text { chlorpromazine, of whom } \\
5 \text { reported regular } \\
\text { cannabis use and } 11 \\
\text { reported daily tobacco } \\
\text { smoking. }\end{array}$ & $\begin{array}{l}\text { predose }(12 \mathrm{~h}) \text { and } 2-4 \mathrm{~h} \\
\text { postdose concentrations. }\end{array}$ & $\begin{array}{l}\text { controlling for age and tobacco } \\
\text { smoking. Estimated increase } \\
\text { higher }(107 \%) \text { with combined } \\
\text { cannabis and tobacco smoking. }\end{array}$ & \\
\hline $\begin{array}{l}\text { (Engels et al., } \\
\text { 2007) }\end{array}$ & $\begin{array}{l}\text { Patients with cancer age } \\
27-67 \text { years receiving } \\
\text { either irinotecan or } \\
\text { docetaxel. }\end{array}$ & $\begin{array}{l}\text { Two consecutive treatments } \\
\text { with irinotecan or docetaxel } \\
(60-90 \text { min infusion), first } \\
\text { alone then with } \\
\text { pretreatment with } \\
\text { marijuana containing tea } \\
\text { (200 mg in } 200 \mathrm{~mL} ; 18 \% \\
\text { THC, } 0.8 \% \text { CBD; } 15 \text { days } \\
\text { total, beginning } 11 \text { days } \\
\text { prior). Premedication for } \\
\text { both treatments: } \\
\text { Irinotecan: granisetron } \\
\text { and dexamethasone } 30 \\
\text { min prior, SC atropine } \\
\text { Docetaxel: } \\
\text { Dexamethasone, for } 3 \\
\text { days starting night } \\
\text { before. }\end{array}$ & $\begin{array}{l}\text { No significant change in irinotecan, } \\
\text { irinotecan metabolite (SN-38 and } \\
\text { its glucuronide), or docetaxel } \\
\text { pharmacokinetic variables, } \\
\text { including AUCs. }\end{array}$ & $\begin{array}{l}\text { Low net } \\
\text { inhibitory/induction } \\
\text { potential of marijuana tea } \\
\text { on major metabolic } \\
\text { pathways for these drugs } \\
\text { and metabolites, including } \\
\text { CYP3A4. }\end{array}$ \\
\hline
\end{tabular}


Figure 1

Title: Cytochrome P-450 (CYP-450) metabolic pathways for cannabinoids and investigated metabolites based on in vitro data.

Caption: Supporting data: (Bland et al., 2005; Bornheim et al., 1992; Chimalakonda et al., 2012; Jiang et al., 2011; Matsunaga et al., 2000; Richardson et al., 1995; Watanabe et al., 2002; Watanabe et al., 1995; Watanabe et al., 2007)

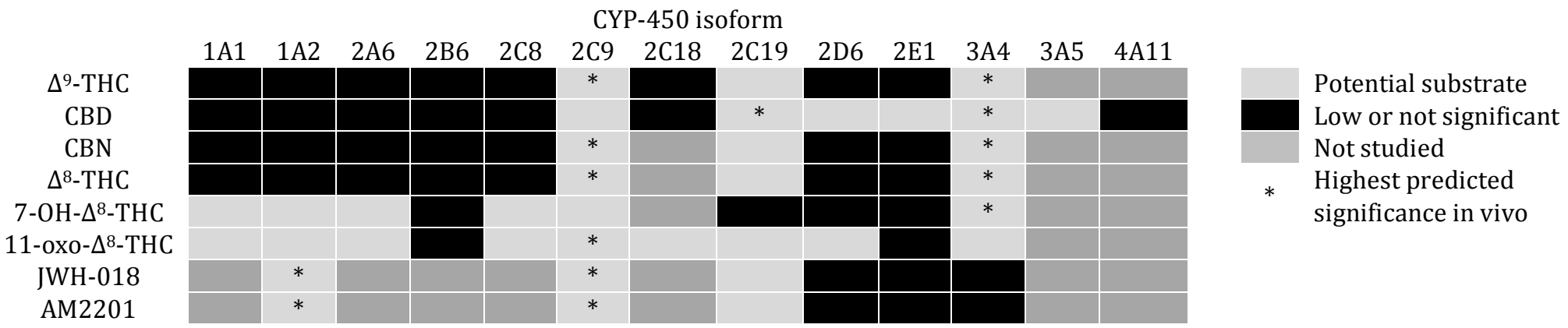


Figure 2

Title: Glucuronidation pathways for exogenous cannabinoids and investigated metabolites in vitro.

Caption: Supporting data: (Chimalakonda et al., 2011; Mazur et al., 2009)

UDP-Glucuronosyltransferase isoform

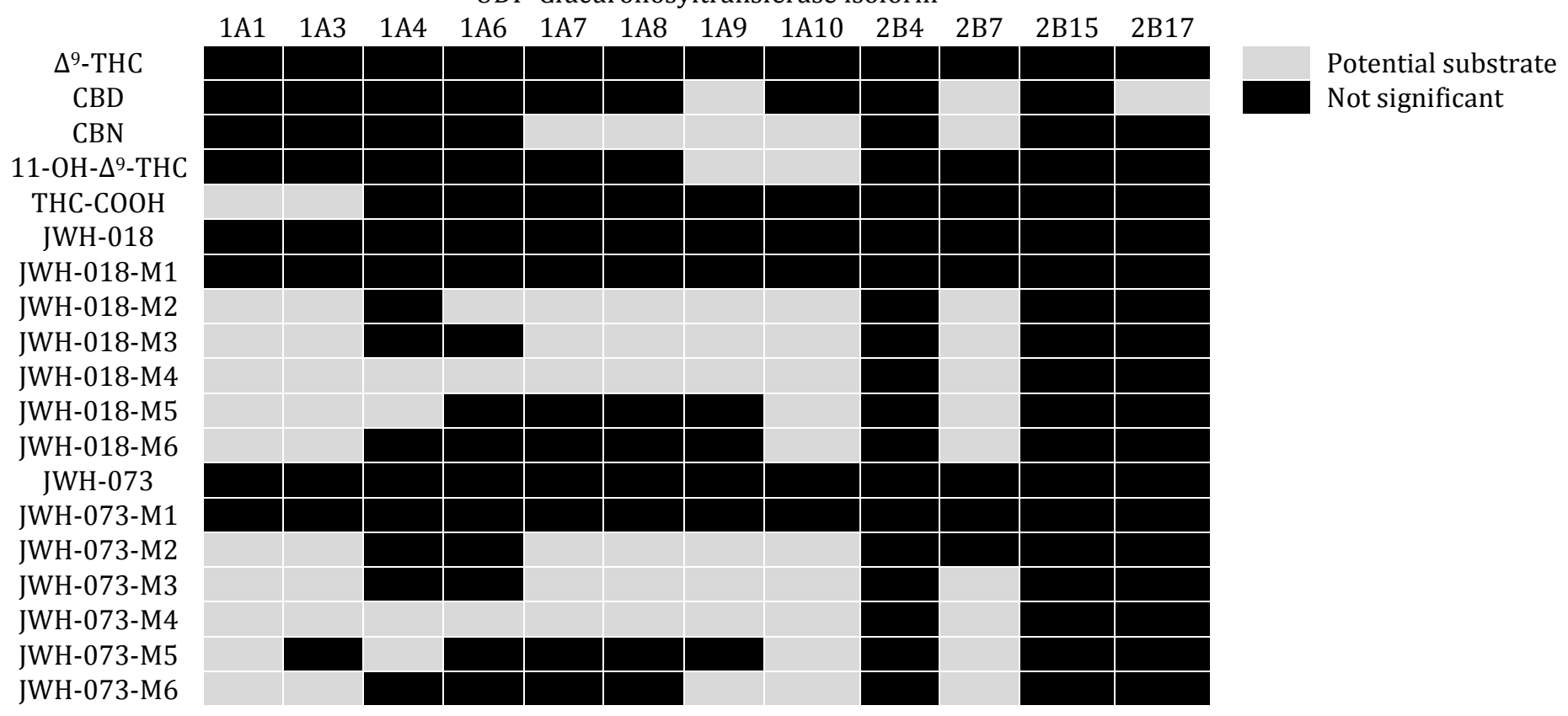




\section{Figure 3}

Title: Chemical structures of the parent cannabinoids for which data were found and included in the review.

Caption: Left side, from top to bottom: THC; CBD; and CBN. Right side, from top to bottom: JWH-018; JWH-073; and AM2201.
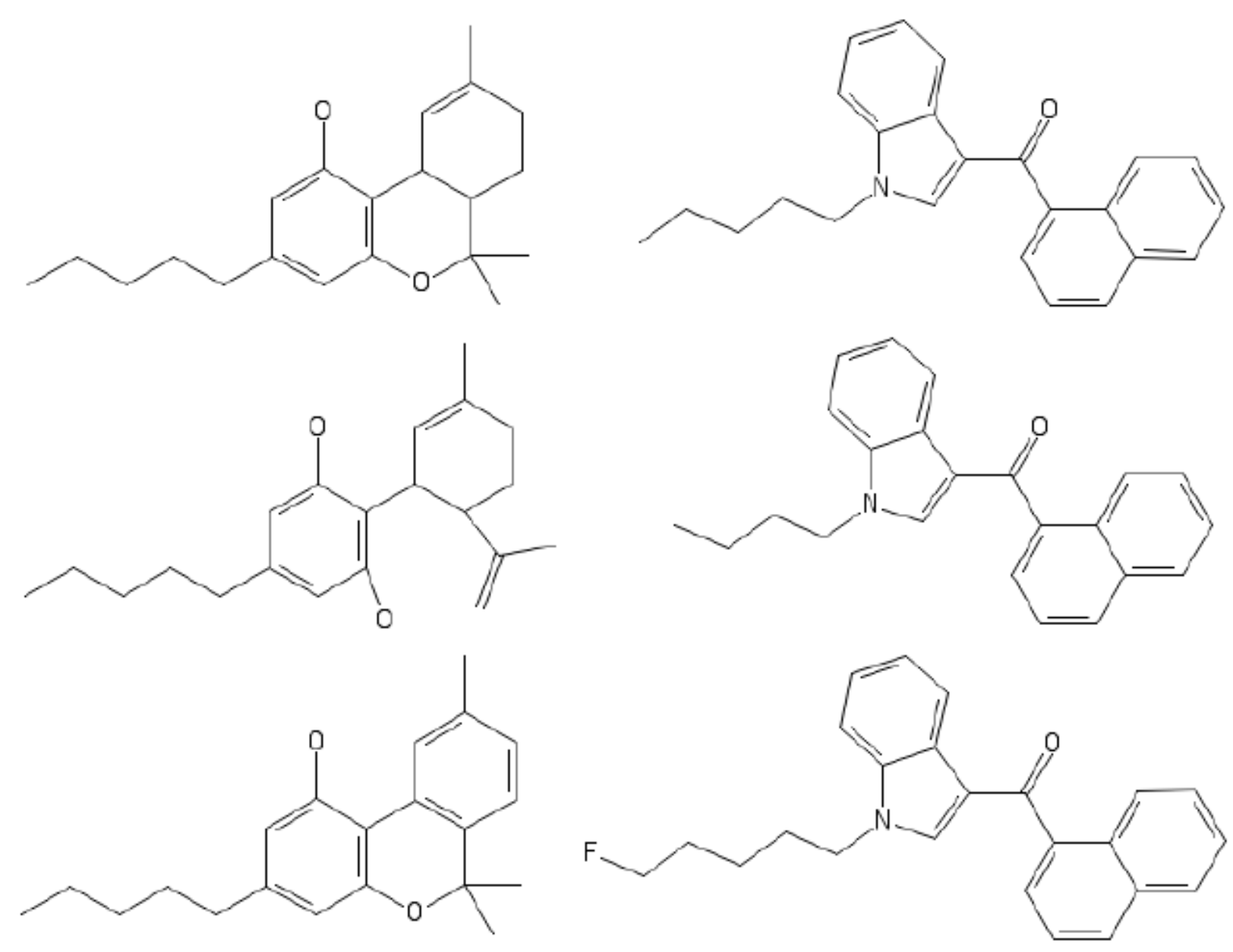